\title{
Association of IL-13, RANTES, and leukotriene C4 synthase gene promoter polymorphisms with asthma and/or atopy in African Americans
}

Ioannis Moissidis, $M D^{1}$, Birjis Chinoy, $M D^{1}$, Krishna Yanamandra, $P h D^{2}$, Dawn Napper, $B S^{2}$, Theodore Thurmon, $M D^{2, \dagger}$, Joseph Bocchini, Jr., $M D^{3}$, and Sami L. Bahna, MD, DrPH

\begin{abstract}
Purpose: IL-13, RANTES (Regulated on Activation, Normal $T$ cells Expressed and Secreted), and cysteinyl leukotrienes are asthma and atopy mediators. Two RANTES -403 (G to A) and -28 (C to G), an -1055 IL-13(C to T), and a -444 (A to C) leukotriene C4 synthase (LTC4S) single nucleotide polymorphisms (SNPs) have been shown in Caucasians and Asians as asthma and atopy risk factors. We studied these SNPs in African Americans with asthma and/or atopy. Methods: We studied 61 patients with asthma and/or atopy and 129 to 157 newborn controls for the -403 RANTES, -28 RANTES, and -1055 IL-13 SNPs, as well as 47 patients and 60 newborn controls for the -444 LTC4S SNP. Results: The two groups did not significantly differ at the genotypes of the -403 and -28 RANTES SNP. On the other hand, the mutant TT genotype for the -1055 IL-13 SNP was detected in $19.7 \%$ of patients versus $12.7 \%$ in controls $(P<0.04$, OR $2.9,95 \% \mathrm{Cl} 1.0-8.0)$, and the mutant $\mathrm{T}$ allele in $58.3 \%$ versus $36.6 \%$ in controls $(P<0.02$, OR 2.4, 95\% Cl 1.1-5.2). In a similar fashion, for the -444 LTC4S SNP, the mutant AC genotype was detected in $19.1 \%$ versus $10.0 \%$ in controls $(P>0.28)$; mutant $C$ allele had an OR of 2.1 (95\% Cl 0.7-6.3). Conclusion: African American asthmatics/atopics had higher frequency of the TT mutant gene for the -1055 IL-13 SNP and of its mutant T allele. Regarding the -444 LTC4S SNP, there was a definite difference, although not statistically significant, with an OR of 2.1 for the mutant AC genotype in patients. If these findings become reproduced by larger studies, it may suggest that IL-13 and LTC4S SNPs can be used as predictive markers for asthma/atopy in African Americans. Genet Med 2005:7(6):406-410.
\end{abstract}

Key Words: asthma, atopy, IL-13, RANTES, LTC4S

Asthma (a chronic complex inflammatory airway disease) and atopy (a condition of hyper-responsiveness of IgE to allergens) are both caused by an interaction between genetic and environmental factors. ${ }^{1}$ Genetic predisposition is probably caused by a characteristic pattern of polymorphism in multiple genes involved in the regulation of the allergic reaction. ${ }^{2} \mathrm{Sev}-$ eral candidate genes for atopy and asthma have been described $^{3-5}$; three of them are IL-13, RANTES (Regulated upon Activation, Normal $T$ cells Expressed and Secreted), and LTC4S (leukotriene C4 synthase) genes.

\footnotetext{
From the ${ }^{1}$ Allergy and Immunology Section, ${ }^{2}$ Genetics Section, and the ${ }^{3}$ Department of Pediatrics, Louisiana State University Health Sciences Center, Shreveport, Louisiana.

Sami L. Bahna, MD, DrPH, Allergy and Immunology Section, LSUHSC Department of Pediatrics, 1501 Kings Highway, Shreveport, LA 71130-3932.

This article has been presented in part (leukotriene C4 synthase) at the Annual Meeting of the American College of Allergy, Asthma and Immunology, November 7-12, 2003, New Orleans, Louisiana, and in part (IL-13 \& RANTES) at the Annual Meeting of the American Academy of Allergy, Asthma and Immunology, March 18-23, 2004, San Francisco, California.

$\dagger$ Decreased.

Received: December 10, 2004.

Accepted: March 28, 2005
}

DOI: 10.1097/01.GIM.0000170994.24960.48
The IL-13 gene lies on chromosome 5q31-33 regions, which contain a number of genes involved in the etiology of allergic asthma. ${ }^{5-8}$ IL-13 promotes the differentiation and survival of eosinophils and mast cells. It also induces the $\operatorname{IgE}$ isotype switch and VCAM-1 expression. However, it inhibits monocyte-mediated antibody-dependent cellular cytotoxicity, proinflammatory cytokine/chemokine production, and nitric oxide secretion. Administration of IL-13 induces eosinophilic infiltration of the airways. ${ }^{9}$ IL-13-overexpressing mice exhibit eosinophilic bronchial inflammation, mucus hypersecretion, fibrosis, eotaxin production, and nonspecific airway hyperreactivity. ${ }^{10}$ The -1055 (C to T) SNP in the promoter region of IL-13 is associated with increased risk of allergic asthma in Dutch Caucasians. ${ }^{11}$

The RANTES gene is located on chromosome 17q11.2q12. ${ }^{28}$ RANTES is a CCL5 chemokine that can induce chemotaxis and activation of several cells (mast cells, eosinophils, baseophils, and T-cells). Higher RANTES levels have been demonstrated in bronchoalveolar lavage fluid of patients with active asthma. ${ }^{12}$ Furthermore, significant rise in plasma RANTES level has been found in asthmatics during acute attacks. ${ }^{13}$ It has been reported that two functional polymorphisms in the proximal promoter region of the RANTES gene 
( $-28 \mathrm{C}$ to $\mathrm{G}$ and $-403 \mathrm{G}$ to $\mathrm{A}$ ) increase transcriptional activity and subsequent RANTES expression in human cell lines. ${ }^{14,15}$ The -403 allele was found to be associated with atopic dermatitis (but not with asthma) in German children, ${ }^{15}$ as well as with increased susceptibility to both asthma and atopy and increased severity of airway obstruction in British population. ${ }^{16}$ The $-28 \mathrm{C}$ to G RANTES SNP represented a genetic risk factor for life-threatening asthma attacks in Chinese children. ${ }^{17}$

Cysteinyl leukotrienes (Cys-LTs) are critical mediators of bronchial smooth muscle contraction and eosinophilia in asthma and atopy. Arachidonic acid is the precursor fatty acid that is transformed into the Cys-LTs by the 5-lipoxygenase (5-LO) pathway. ${ }^{18}$ LTC4S, a 5-LO enzyme, catalyzes the production of the unstable LTC4, which then in the extracellular environment is converted to its bioactive metabolites LTD4 and LTE4. An -444(A to C) LTC4S SNP was identified in the gene promoter region of the chromosome $5 \mathrm{q}^{3} 5^{19}$ and was predicted to create an extra recognition site for the AP- 2 transcription factor and lead to increased gene transcription (transcriptional upregulation). Hence, the $-444 \mathrm{C}$ mutant allele is a risk factor for aspirin-induced asthma (AIA). ${ }^{20}$ The role of LTC4S promoter polymorphism in AIA is unclear, with several studies indicating a functional role, ${ }^{21}$ whereas others question its significance. ${ }^{22}$ The $-444 \mathrm{C}$ allele is present in $20 \%$ to $30 \%$ of the general Caucasian and Asian population. ${ }^{23}$

There is no data on African Americans on the association of the RANTES - 403( $\mathrm{G}$ to A) and -28(C to G), IL-13 - 1055(C to T), or LTC4S - 444(A to C) SNP with asthma and/or atopy. Hence, we investigated the possibility of such an association.

\section{MATERIALS AND METHODS}

\section{Subjects}

Our subjects were African Americans from Northwestern Louisiana who have been followed at the Allergy/Immunology Clinics of the Louisiana State University Health Sciences Center with already established diagnoses of allergic rhinitis, bronchial asthma, atopic dermatitis, or combinations. The diagnosis was established according to the classic findings in the medical history, physical examination, and relevant laboratory tests. Empirically the total group was referred to as "asthma/ atopy" and composed of 61 patients 2 to 74 years of age.

Atopy was determined by a positive allergy skin test or serum specific IgE to common environmental allergens. Skin testing was done by the prick method (SPT) and the reaction was considered positive if it was $\geq 2+$, compared to histamine $(1: 1000)$ and a negative control. More specifically scoring of the SPT was considered $\geq 2+$ if the response was larger than the negative control by $50 \%$ to $75 \%$ (wheal diameter at least 3 $\mathrm{mm}$ ), and as $\geq 4+$, the response larger than the positive histamine control by $25 \%$ to $50 \%$ (wheal with pseudopodes). ${ }^{26}$

Serum specific IgE antibody level was measured by the ImmunoCAP method (Pharmacia Diagnostics, Kalamazoo, MI) and was considered positive if $\geq 0.35 \mathrm{kU} / \mathrm{L}$. According to the laboratory's criteria, the test results was considered $2+$ for spe- cific IgE levels of 0.71 to $3.50 \mathrm{kU} / \mathrm{L}, 3+$ for levels of 3.51 to $17.51 \mathrm{kU} / \mathrm{L}$, and $4+$ for levels of 17.51 to $50.00 \mathrm{kU} / \mathrm{L} .{ }^{27}$

Patients' DNA was compared with that of healthy African American newborn controls: 129 to 157 for IL-13 and RANTES and 60 for LTC4S. The polymorphic assays on controls were performed on newborns' DNA stored specimens that were obtained for previous studies.

\section{Genotyping}

PCR-restriction fragment length polymorphism was used. ${ }^{25}$ Aliquots of PCR products were subjected to $2 \%$ agarose gel electrophoresis. The IL-13, RANTES, and LTC4S genotyping and PCR conditions are summarized in Table 1. Genotyping assays for LTC4S SNP (47 patients) and for IL-13 and RANTES (61 patients) were originally done for two separate investigations that were presented as abstracts at two different meetings. In this article, we combined the two pieces of work, hence the discrepancy in numbers.

\section{Statistical analysis}

The association between the asthma and/or atopy and the polymorphic alleles was analyzed in our data using the Chisquare test. The association was considered significant if the $P$ value was $<0.05$.

\section{RESULTS}

\section{IL-13, RANTES, and LTC4S genotypes of asthma and/or atopy patients in comparison to healthy controls}

Table 2 shows the comparison of the three IL-13, RANTES, and LTC4S SNPs, in asthma/atopy patients versus healthy controls. The $P$ value was statistically significant $(P<0.04$, odds ratio $2.9,95 \%$ CI $1.0-8.0$ ) only for the IL-13 TT mutant allele. Regarding the LTC4S SNP, the $P$ value was not significant $(P>$ $0.28)$, but the odds ratio of the $\mathrm{C}$ allele was $2.1(95 \% \mathrm{CI}=$ $0.7-6.3)$.

\section{IL-13 - 1055TT, RANTES -403AA, and LTC4S -444AC mutant genotypes according to atopic disease}

We analyzed the data according to the three major atopic diagnoses, i.e., allergic rhinitis (AR), bronchial asthma (BA), and atopic dermatitis (AD). Compared to controls, no statistically significant differences were noted for any of the three SNPs studied (Table 3).

\section{Relationship of allergen sensitization and IL-13, RANTES, and LTC4S SNPS}

We investigated the possible relationship of the SNPs to the degree of positivity (i.e., sensitization) to the aeroallergen skin prick tests (SPT) or the specific IgE (Table 4). Because normal subjects can have a positive skin test or serum specific IgE to one or a few aeroallergens without clinical relevance, we classified our patients into 2 groups ( $\geq 2+$ and $\geq 4+$ ) according 
Table 1

PCR primers, assay conditions, and restriction enzymes for genotyping

\begin{tabular}{|c|c|c|c|c|c|c|c|}
\hline \multicolumn{2}{|c|}{ Polymorphism } & \multirow{2}{*}{$\frac{\text { Primers }\left(5^{\prime}, 3^{\prime}\right)}{\text { rGGGAGTCAGAGCCA-3' }}$} & \multirow{2}{*}{$\frac{\mathrm{MgCl}_{2}}{3.25 \mathrm{mM}}$} & \multirow{2}{*}{$\begin{array}{c}\begin{array}{c}\text { Annealing } \\
\text { Temp. }{ }^{\circ} \mathrm{C}\end{array} \\
62\end{array}$} & \multirow{2}{*}{$\begin{array}{c}\begin{array}{c}\text { Restriction } \\
\text { enzyme }\end{array} \\
\text { Hpy99 I }\end{array}$} & \multirow{2}{*}{$\frac{\text { Alleles }}{\text { CC }}$} & \multirow{2}{*}{$\begin{array}{c}\text { Fragment sizes } \\
\text { (bp) }\end{array}$} \\
\hline IL-13 & $\mathrm{C}-1055 \mathrm{~T}$ & & & & & & \\
\hline & & 5'-TACAGCCATGTCGCCTTTTCCTGCTCTTCCGTC-3' & & & & TT & 372 \\
\hline & & & & & & $\mathrm{CT}$ & 33933372 \\
\hline \multirow[t]{3}{*}{ RANTES } & G-403A & 5'-CACAAGAGGACTCATTCCAACTCA-3' & $2.6 \mathrm{mM}$ & 55 & Rsa I & GG & 18026 \\
\hline & & 5'-GTTCCTGCTTATTCATTACAGATCGTA-3' & & & & GA & 20618026 \\
\hline & & & & & & $\mathrm{AA}$ & 206 \\
\hline \multirow[t]{3}{*}{ RANTES } & C-28G & 5'-ACTCCCCTTAGGGGATGCCCGT-3' & $2.6 \mathrm{mM}$ & 55 & Hinc II & $\mathrm{CC}$ & 15223 \\
\hline & & 5'-GCGCAGAGGGCAGTAGCAAT-3' & & & & CG & 17515223 \\
\hline & & & & & & GG & 175 \\
\hline \multirow[t]{3}{*}{$\mathrm{LTC}_{4} \mathrm{~S}$} & A- $444 \mathrm{C}$ & 5'-CAACGACTAAGGCTGGCAGG-3' & $2.5 \mathrm{mM}$ & 62 & Msp I & AA & 199 \\
\hline & & 5'-CACTTTCTCCAGGGCCTTGC-3' & & & & $\mathrm{AC}$ & 167199 \\
\hline & & & & & & $\mathrm{CC}$ & 167 \\
\hline
\end{tabular}

Table 2

IL-13, RANTES, and $\mathrm{LTC}_{4} \mathrm{~S}$ genotype of asthma and/or atopy patients compared to controls

\begin{tabular}{|c|c|c|c|c|c|}
\hline & & Asthma/atopy & Controls & $\mathrm{p}$ value & Odds ratio \\
\hline \multirow[t]{3}{*}{ IL-13 - 1055} & $\mathrm{CC}$ & $13(21.3 \%)$ & $62(39.5 \%)$ & & \\
\hline & CT & $36(59.0 \%)$ & $75(47.8 \%)$ & & \\
\hline & TT & $12(19.7 \%)$ & $20(12.7 \%)$ & & \\
\hline \multirow[t]{2}{*}{ Total patients } & & 61 & 157 & 0.04 & 2.9 \\
\hline & & & & TT mutant & $95 \% \mathrm{CI}=1.0-8.0$ \\
\hline \multirow[t]{3}{*}{ RANTES -403} & GG & $16(26.2 \%)$ & $35(26.7 \%)$ & & \\
\hline & GA & $34(55.7 \%)$ & $72(55.0 \%)$ & & \\
\hline & $\mathrm{AA}$ & $11(18.0 \%)$ & $24(18.3 \%)$ & & \\
\hline Total patients & & 61 & 131 & $\mathrm{NS}^{*}$ & \\
\hline \multirow[t]{3}{*}{ RANTES -28} & $\mathrm{CC}$ & $59(96.7 \%)$ & $129(100 \%)$ & & \\
\hline & CG & $2(3.3 \%)$ & $0(0 \%)$ & & \\
\hline & GG & $0(0 \%)$ & $0(0 \%)$ & & \\
\hline Total patients & & 61 & 129 & $\mathrm{NS}^{*}$ & \\
\hline \multirow[t]{2}{*}{$\mathrm{LTC}_{4} \mathrm{~S}-444$} & AA & $38(80.6 \%)$ & $54(90.0 \%)$ & & \\
\hline & $\mathrm{AC}$ & $9(19.1 \%)$ & $6(10.0 \%)$ & & \\
\hline \multirow[t]{2}{*}{ Total patients } & & 47 & 60 & 0.303 (NS) & 2.01 \\
\hline & & & & AC Mutant & $95 \% \mathrm{CI}=0.624-6.656$ \\
\hline
\end{tabular}

NS, Not significant.

to the degree of positivity to at least $50 \%$ of the allergens tested in each individual patient. We found statistically significant difference in the category of sensitization $\geq 2+$ of the IL-13 T mutant allele ( $P$ value 0.019 , odds ratio $2.42,95 \% \mathrm{CI}=1.143$ $5.165)$ in comparison to newborn controls.

\section{DISCUSSION}

Different polymorphisms have been previously identified in candidate genes associated with asthma and/or atopy in Caucasians. In the present study on African Americans, we inves- 
Table 3

IL-13 - 1055 TT, RANTES - $403 \mathrm{AA}$, and $\mathrm{LTC}_{4} \mathrm{~S}-444 \mathrm{AC}$ mutant SNPs in allergic rhinitis (AR), bronchial asthma (BA), and atopic dermatitis (AD)

\begin{tabular}{|c|c|c|c|c|c|c|c|c|c|c|c|c|c|c|}
\hline \multirow[b]{2}{*}{ DIAGNOSIS } & \multicolumn{5}{|c|}{ IL-13 - 1055} & \multicolumn{5}{|c|}{ RANTES -403} & \multicolumn{4}{|c|}{$\mathrm{LTC}_{4} \mathrm{~S}-444$} \\
\hline & $n$ & $\begin{array}{c}\text { CC } \\
\text { Wild }\end{array}$ & $\begin{array}{c}\text { TT } \\
\text { Mutant }\end{array}$ & CT & $P$ Value & $n$ & $\begin{array}{l}\text { GG } \\
\text { Wild }\end{array}$ & $\begin{array}{c}\text { AA } \\
\text { Mutant }\end{array}$ & GA & $P$ Value & $n$ & $\begin{array}{c}\text { AA } \\
\text { Wild }\end{array}$ & $\begin{array}{c}\text { AC } \\
\text { Mutant }\end{array}$ & $P$ Value \\
\hline AR & 46 & 8 & 6 & 32 & NS & 46 & 11 & 6 & 29 & NS & 37 & 30 & 7 & NS \\
\hline BA & 38 & 6 & 9 & 23 & NS & 38 & 13 & 4 & 21 & NS & 30 & 26 & 4 & NS \\
\hline $\mathrm{AD}$ & 16 & 3 & 4 & 9 & NS & 16 & 4 & 2 & 10 & NS & 13 & 10 & 3 & NS \\
\hline
\end{tabular}

NS, Not significant compared with African American newborn controls.

Table 4

Number of patients genotyped among those positive by allergy skin prick test/specific IgE in IL-13, RANTES - 403, and LTC 4 S SNPs, according to degree of positivity to at least $50 \%$ of allergens tested

\begin{tabular}{|c|c|c|c|c|c|c|c|c|c|c|c|c|c|c|}
\hline \multirow{2}{*}{$\begin{array}{l}\text { SPT/sIgE } \\
\text { Score }\end{array}$} & \multicolumn{5}{|c|}{ IL-13 C $-1055 \mathrm{~T}$} & \multicolumn{5}{|c|}{ RANTES G $-403 \mathrm{~A}$} & \multicolumn{4}{|c|}{$\mathrm{LTC}_{4} \mathrm{~S} \mathrm{~A}-444 \mathrm{C}$} \\
\hline & $n$ & $\mathrm{CC}$ & $\mathrm{TT}$ & $\mathrm{CT}$ & $P$ value & $n$ & GG & AA & GA & $P$ value & $n$ & AA & $\mathrm{AC}$ & $P$ value \\
\hline \multirow[t]{2}{*}{$\geq 2+$} & 18 & 1 & 4 & 13 & 0.019 & 18 & 2 & 1 & 15 & NS & 15 & 13 & 2 & NS \\
\hline & $(100 \%)$ & $(5.5 \%)$ & $(22.2 \%)$ & $(71.5 \%)$ & & $(100 \%)$ & $(11.1 \%)$ & $(5.5 \%)$ & $(83.3 \%)$ & & $(100 \%)$ & $(86.6 \%)$ & $(13.3 \%)$ & \\
\hline \multirow[t]{2}{*}{$\geq 4+$} & 5 & 1 & 1 & 3 & NS & 5 & 1 & 1 & 3 & NS & 3 & 3 & 0 & NS \\
\hline & $(100 \%)$ & $(20 \%)$ & $(20 \%)$ & $(60 \%)$ & & $(100 \%)$ & $(20 \%)$ & $(20 \%)$ & $(60 \%)$ & & $(100 \%)$ & $(100 \%)$ & $(0 \%)$ & \\
\hline
\end{tabular}

NS, Not significant compared with African American newborn controls.

tigated the association of three critical SNPs (IL-13, RANTES, and LTC4S) that control the expression of important asthma and/or atopy molecules.

We found statistically significant difference in the IL-13 -1055 TT mutant genotype in our patients, compared to African American newborn controls. This is consistent with the findings of a similar study on this specific SNP in a Dutch Caucasian population. ${ }^{11}$

There was no significant difference between the patients and controls regarding RANTES -403 and -28 SNP. An association has been previously reported of the -403 RANTES SNP with atopic dermatitis, but not with asthma, in German children ${ }^{15}$ as well as an increased susceptibility to asthma/atopy, and increased severity of airway obstruction in a British population. ${ }^{16}$

The -444 LTC4S SNP has been studied before in Caucasian and Japanese patients with aspirin-induced asthma (AIA) and aspirin tolerant asthma (ATA). The presence of the C allele was identified as a risk factor for AIA Caucasian patients compared with ATA or healthy subjects (odds ratio 3.89). ${ }^{20}$ The role of the LTC4S promoter SNP in AIA is unclear. One study supports its functional role, ${ }^{21}$ whereas three others question its significance. ${ }^{22-24}$ Our study is the first to suggest a role for LTC4S SNP in the development of asthma/atopy in African Americans, with an odds ratio of 2.01 (95\% CI 0.624-6.656), although the association was not statistically significant, possibly due to the small sample size. Nevertheless, our findings are probably valid by their similarity to those in previous studies on Caucasian ${ }^{20}$ or Asian ${ }^{23}$ populations.

Larger studies are needed to validate our findings, which would suggest that IL-13 and LTC4S SNPs can be used as predictive markers for asthma/atopy in African Americans.

\section{References}

1. Borish L, Rosenwasser LJ. Cytokines in allergic inflammation. In: Adkinson NF, Yunginger JW, Busse WW, editors. Middleton's Allergy Principles and Practice. Philadelphia: Mosby, 2003;141-158.

2. Koppelman GH, Stine OC, Xu J. Genome-wide search for atopy susceptibility genes in Dutch families with asthma. J Allergy Clin Immunol 2002;109:498-506.

3. The Collaborative Study of the Genetics of Asthma (CSGA). A genome-wide search for asthma susceptibility loci in ethnically diverse populations. Nat Genet 1997;15: 389-392.

4. Dizier MH, Besse-Schmittler C, Guilloud-Bataille M. Genome screen for asthma and related phenotypes in the French EGEA study. Am J Respir Crit Care Med 2000;162:1812-1818.

5. Nillson G, \& Nillson K. Effects of IL-13 on immediate-early response gene expression, phenotype and differentiation of human mast cells. Comparison with IL-4. Eur J Immunol 1995;25:870-873.

6. McKenzie AN. Interleukin-13, a T cell-derived cytokine that regulates human monocyte and B cell function. Proc Natl Acad Sci USA 1993;90:3735-3739.

7. Zurawski G, de Vries JE. Interleukin 13, an interleukin 4-like cytokine that acts on monocytes and B cells, but not on T cells. Immunol Today 1994;15:19-26.

8. Bochner BS. IL-13 selectively induces vascular cell adhesion molecule-1 expression in human endothelial cells. J Immunol 1995;154:799-803.

9. Wills-Karp M. Interleukin-13: Central mediator of allergic asthma. Science 1998; 282:2258-2261.

10. Zhu Z. Pulmonary expression of interleukin-13 causes inflammation, mucus hypersecretion, subepithelial fibrosis, physiologic abnormalities, and eotaxin production. J Clin Invest 1999;103:779.

11. Van der Pouw Kraan T, van Veen A, Boeije L. An IL-13 promoter polymorphism associated with increased risk of allergic asthma. Genes Immun 1999;1:61-65.

12. Alam R, York J, Stafford S. Increased MCP-1, RANTES and MIP-1 alpha in bronchoalveolar lavage fliud of allergic asthmatic patients. Am J Respir Crit Care Med 1996;153:1398-1404.

13. Chihara J, Yasuda H, Tsuda A. Elevation of the plasma levels of RANTES during asthma attacks. J Allergy Clin Immunol 1997;100:S52-S55.

14. Liu H, Chao D, Nakayama EE. Polymorphism in RANTES chemokine promoter affects HIV-disease progression. Proc Natl Acad Sci USA 1999;96:4581-4585.

15. Nickel RG, Casolaro V, Wahn U. Atopic dermatitis is associated with a functional mutation in the promoter of the C-C chemokine RANTES. J Immunol 2000;164: 1612-1616.

16. Fryer AA, Spiteri MA, Bianco A. The -403 GtoA promoter polymorphism in the RANTES gene is associated with atopy and asthma. Genes Immun 2000;1:509-14. 
17. Yao TC, Kuo ML, See LC. The RANTES promoter polymorphism: A genetic risk factor for near-fatal asthma in Chinese children. J Allergy Clin Immunol 2003;111: 1285-1892.

18. Drazen JM, Israel E, O'Byrne PM. Treatment of asthma with drugs modifying the leukotriene pathway. N Engl J Med 1999;340:197-206.

19. Sayers I, Barton S, Rorke S. Allelic association and functional studies of the promoter polymorphism in the leukotriene C4 synthase gene (LTC4S) in asthma. Thorax 2003;58:417-424.

20. Sanak M, Simon HU, Szczeklik A. Leukotriene C4 synthase promoter polymorphism and risk of aspirin-induced asthma. Lancet 1997;350:1599-1600.

21. Szczeklik A, Sanak M. Genetic mechanism in aspirin-induced asthma. Am J Respir Crit Care Med 2000;161:S142-S146.

22. Van Sambeek R, Stevenson DD, Baldasaro M. 5 ' flanking region polymorphism of the gene encoding leukotriene $\mathrm{C} 4$ synthase does not correlate with the aspirin-intolerant asthma phenotype in the United States. J Allergy Clin Immunol 2000;106:72-76.
23. Kawagishi Y, Mita H, Taniguchi M. Leukotriene C4 synthase promoter polymorphism in Japanese patients with aspirin-induced asthma. J Allergy Clin Immunol 2002;109:936-942.

24. Brauer J, Amelung P, Meyers D. Association of asthma susceptibility and severity with a polymorphism in the leukotriene C4 (LTC4) synthase gene. Am J Respir Crit Care Med 1999;159:A650-A.

25. Yanamandra K, Rodriquez-Paris J, Smith M. Prothrombin polymorphism and lung cancer. The Am J Hum Genet 2003;73:75.

26. Bahna SL. Diagnostic tests for food allergy. Clin Rev Allergy 1988;6:259-282.

27. Hamilton RG. Laboratory tests for allergic and immunodeficiency diseases. In: Adkinson NF, Yunginger JW, Busse WW, editors. Middleton's Allergy Principles and Practice. Philadelphia: Mosby, 2003;622.

28. Donlon TA, Krensky AM, Wallace MR. Localization of a human T-cell-specific gene, RANTES (D17S136E), to chromosome 17q11.2-q12. Genomics 1990;3:548553. 